JäAL JOALL (JOURNAL OF APPLIEI) LINGUIS'TICS ANI) LI'TERA'TURE)

Vol. 7 No. 1, February 2022

ISSN (print): 2502-7816; ISSN (online): 2503-524X

Available online at https:/ / ejournal.unib.ac.id/index.php/joall/article/view/12540

http://doi.org/10.33369/joall.v7i1.12540

\title{
Continuous professional development: An overview from English language teachers in east Kalimantan
}

\author{
1,2Abdul Halim (iD), ${ }^{2}$ Yih-Sheue Lin, ${ }^{3}$ Mustofa ${ }^{(D)}$, ${ }^{4}$ Khusnul Khatimah \\ 1,4English Education Department, Universitas Muhammadiyah Kalimantan Timur, INDONESIA \\ ${ }^{1}$ Jalan Ir. H Juanda 15, Samarinda \\ ${ }^{2}$ Department of Education and Human Potentials Development, National Dong Hwa \\ University, TAIWAN (ROC) \\ ${ }^{2}$ No. 1 號, Section 2, Daxue Rd, Shoufeng Township, Hualien County, 974 \\ 3 Primary Teacher Education Department, Universitas Nahdlatul Ulama Surabaya, INDONESIA \\ 3 Jalan Smea No. 57, Surabaya
}

\begin{tabular}{|c|c|}
\hline ARTICLE INFO & ABSTRACT \\
\hline $\begin{array}{l}\text { Article history: } \\
\text { Received: Sept 16, } 2020 \\
\text { Revised: Aug 04, } 2021 \\
\text { Accepted: Dec 06, } 2021\end{array}$ & \multirow{5}{*}{$\begin{array}{l}\text { The purpose of the study was to explore how continuous } \\
\text { professional development is conducted, who conducts it, and } \\
\text { the factors that influence it. According to the laws of the } \\
\text { Republic of Indonesia, teaching is a professional job that } \\
\text { requires certain educational and training qualifications so } \\
\text { that teachers can become professional personnel. By seeing } \\
\text { the importance of professionalism in this work and in order } \\
\text { to see the picture of the CPD of teachers in East Kalimantan, } \\
\text { this research is important to carry out. This research uses a } \\
\text { qualitative case study method. The subjects of this study were } \\
\text { teachers (n=10) from ten schools in Samarinda, Kutai } \\
\text { Kartanegara, and Balikpapan. Data were collected using a } \\
\text { CPD questionnaire and interviews. The data obtained were } \\
\text { analysed and presented with descriptions and tables or } \\
\text { charts. The data indicated that most of the teachers } \\
\text { participated in the study are aware of the components of } \\
\text { professional teacher indicated from the government laws. The } \\
\text { study also reveals how the CPD is conducted by different } \\
\text { stakeholders. Some suggestions are proposed based on the } \\
\text { results of the study. }\end{array}$} \\
\hline $\begin{array}{l}\text { Keywords: } \\
\text { Professional development } \\
\text { Education } \\
\text { Teacher } \\
\text { Training }\end{array}$ & \\
\hline $\begin{array}{l}\text { Conflict of interest: } \\
\text { None }\end{array}$ & \\
\hline $\begin{array}{l}\text { Funding information: } \\
\text { Directorate of Research and } \\
\text { Community Service of the Republic } \\
\text { of Indonesia } 2019\end{array}$ & \\
\hline $\begin{array}{l}\text { Correspondence: } \\
\text { Abdul Halim, Department of } \\
\text { Education and Human Potentials } \\
\text { Development, National Dong Hwa } \\
\text { University, TAIWAN. } \\
\text { ah918@umkt.ac.id }\end{array}$ & \\
\hline
\end{tabular}

c) (7) (2) ๑Abdul Halim, Yih-Sheue Lin, Mustofa, Khusnul Khatimah

This is an open access article under the CC BY-SA 4.0 international license.

\section{How to cite (APA Style):}

Halim, A., Lin, Y., Mustofa, Khatimah, K. (2022). Continuous professional development: An overview from English language teachers in east Kalimantan. JOALL (Journal of Applied Linguistics and Literature), Vol (Issue), page-page. https://doi.org/10.33369/joall.v7i1.12540 


\section{Professionalism in education has been an issue that brought up a} dispute among the society for more than three decades ago. A question was arisen whether or not a teaching is a professional job such as doctors or lawyers. In order to answer the question, professional jobs are characterized by some attributes making it different from the common labors. Teachers, in this sense, should possess these attributes such as structured skills and knowledge, commitments, and act on behalf of their clients/stakeholders so that it can be included as a professional job (Carr \& Kemmis, 1986). In 2005 the Indonesian Government have acknowledged the teachers' profession as a part of professional occupation with Indonesian laws Number 14 Year 2005 (Undang-Undang Republik Indonesia Nomor 14 Tahun 2005 Tentang Guru Dan Dosen, 2005). It guaranteed the profession with the attributes of four competences namely the competency of pedagogy, social, personal, and professional. Therefore, it is important to picture how these competencies are maintained by all the stakeholders in education: education authorities, teachers' association, school leaders, and the teachers.

There are several studies that have been conducted related to teacher professionalism in Indonesia. The first is the research conducted by Anugerahwati \& Saukah (2010). This study explored how teachers developed teacher professionalism by exemplary teachers in Malang, Sidoarjo, Lawang, and Solok. In their study, the researchers focused on exemplary teachers as research subjects. The results of this study, it can be predicted that these teachers have a very good understanding and implementation of CPD. These teachers have high competence in almost all aspects of professionalism. However, there is a gap that remains in question, that is what and how can they see and consistently implement CPD? Do all teachers in their home base schools have equal opportunities in professional development?

The next research is research conducted by Mustafa (2013). He examined the quality of teachers' professional perceptions and differences in gender perspectives and work experience. By using the competency test instrument, 327 assessment teachers were in their research in Pekanbaru. The results show that the teachers have equal competence. His research also reports that there is difference in the results of competency tests between men and women. The difference is also based on work experience. However, research bias can occur in relation to different contexts, the opportunities each teacher has in different subject areas based on government policies and the creativity of KKG, MGMP, or MKKS in the local location. It is also interesting to note; namely if the differences occur in the narrower field, for instance in the same field of study?

The third research was conducted by Tanang \& Abu (2014). In their study, they tried to determine the profile of teacher professionalism in 
Indonesia by choosing South Sulawesi as the research location. In this study, behavior, pedagogical abilities, and diversity of learning activities became a central part of the study. In addition, it also identifies obstacles in developing CPD. Similar to previous research, it was found that gender can influence perspectives on CPD. In addition, in this study they found that academic qualification also influenced learning activities and pedagogical abilities. Is this the only factor?

The purpose of the study was to explore who conducts continuous professional development for English language teacher and how it is conducted, and the factors that influence it. Therefore, the significance of the study can be accurate to fill in the gap of previous research and to contribute more specifically on the localized applicable contexts.

\section{METHOD}

\section{Participants}

The participants of this study were ten teachers from different schools across East Kalimantan province in three cities: Samarinda, Balikpapan, Kutai Kartanegara. They have been teachers for at least 5 years. Six out of 10 have been in their teaching career for 10 years. The schools were chosen randomly and checked for accessibility. In the beginning curtained schools were already selected for study inclusion. However, due to COVID-19 some refused the request but the researchers kept the effort to make ten different schools available.

There were two schools from Balikpapan, five schools from Samarinda, and three schools from Kutai Kartanegara. Out of ten, two schools are private, and the rests are state schools. It is also imperative to note that the private schools are privileged. So that it may affect data deduction. At the same time, two schools from Kutai Kartanegara are state schools in the suburban area.

\section{Instruments}

The study utilized two instruments for data collection: interview and equestionnaire. The interview protocol was developed to collect the data regarding the teachers' awareness of the CPD, stakeholders for CPD, which of the competencies they have obtained through CPD programs, and factors influencing the CPD. The questions were semi structured for interview consisting ten questions for all aspects mentioned above. The e-questionnaire was used to identify the 12 components of CPD based on British Council courtesy. The questionnaire was in the form of Google form which asks the participants types of CPD according to British Council framework (closeended) and added with one options that the teachers were free to write any other type of the CPD they ever had. Both interview questions and 
questionnaire were in Indonesian language. Later, the obtained data were confirmed to the participants before they were translated into English.

\section{Data analysis procedures}

After the data from the interview was collected, the interview note was used to identify the theme of the problem according to the research problem. The researchers sorted the data based on the similarities and differences of data and labelled them according to the data groups which later was used to see the finding and discussed it with the related literature. Some of the data which contained numeric results were analyzed by using Ms. Excel program and the data were exported in the form of charts and graphs. Regarding the data from the e-questionnaire, the raw data were downloaded from the Google from. These data were, then, extracted to Microsoft excel descriptive statistics application. The teachers' types of CPD were then successfully collected to describe their current CPD experience.

\section{FINDINGS}

\section{Situation}

The participants of this study were teachers $(n=10)$ who served in East Kalimantan with a distribution of 3 district and cities, namely Samarinda, Balikpapan, and Kutai Kartanegara. The data were collected from May-July 2020 from ten teachers from various public and private schools in urban and rural areas. However, the data we took was limited due to the COVID-19 situation which is currently becoming a pandemic with an epicenter in Samarinda and Balikpapan.

\section{Awareness of continuous professional development}

Based on the results of the interview, in general, nine out of ten participants in this study said that they were aware and knew the competence of teachers that they must master as a professional teacher. However, one of them did not know the four components mandated by the laws about teachers and lecturers Number 14 Year 2005. The results of the interviews showed that the participants understood this competency from various sources, including lectures during their studies in college, materials for teacher competency test (UKG), and school development programs.

\section{Stakeholders conducting continuous professional development}

Most of the CPD programs, which were implemented to improve the professionalism of school teachers, were carried out by the school itself, then followed by teacher associations such as MGMP for each subject. Meanwhile, the third place is by the Education Authority. Among the three districts and cities, Kutai Kartanegara Regency is the one that holds the most frequent CPD 
for teachers in its area and even one of the participants has participated in the CPD program held by the district government to England for Cambridge Teacher Knowledge Test (TKT). Then there were three participants who had their own initiative to take part in various kinds of training in order to improve their individual professionalism.

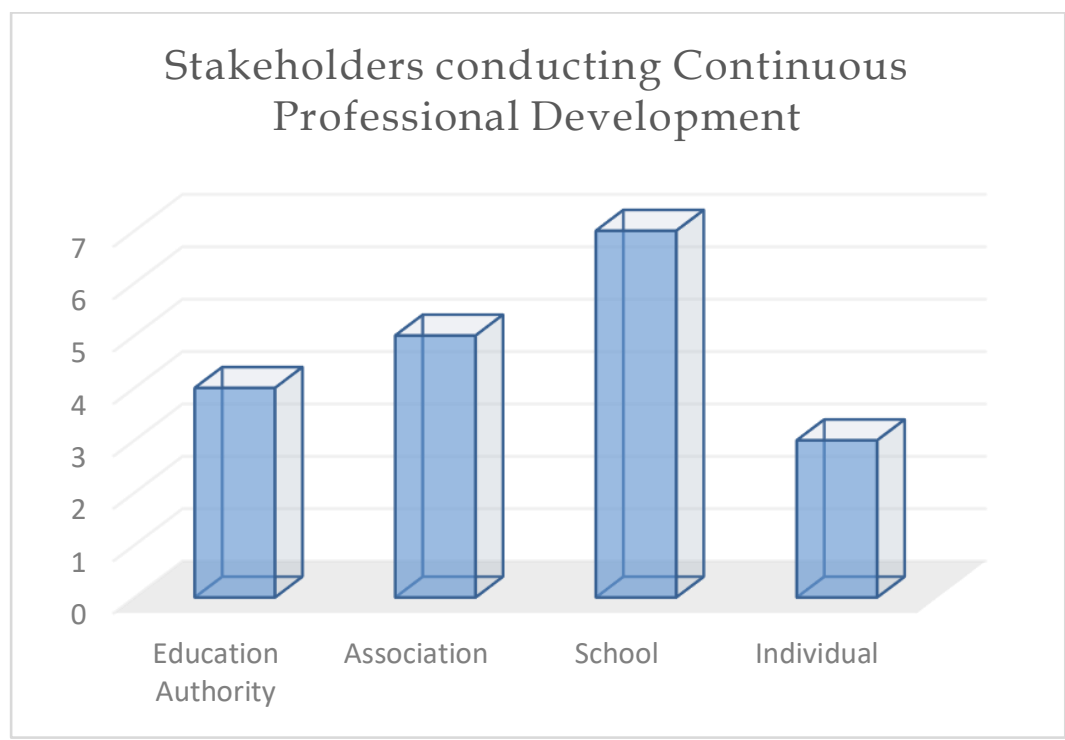

Chart 1. The stakeholders

\section{Programs to improve competencies}

The findings in this section are interesting to note. First, the Law about Teachers and Lecturers Number 14 of 2005 explicitly states that there are four main competencies that must be possessed by teachers. However, the reality in the field, many interested parties such as the Education Authority under the Ministry of Education, schools, teacher associations, or individuals placed the four competencies differently in their priority. Most of the stakeholders were focusing on pedagogical competence and professional competence so that all participants disclose that they have never received special training from the stakeholders that can develop their social competences and personal competences. These competences were acquired personally with individual development by the school teachers. 


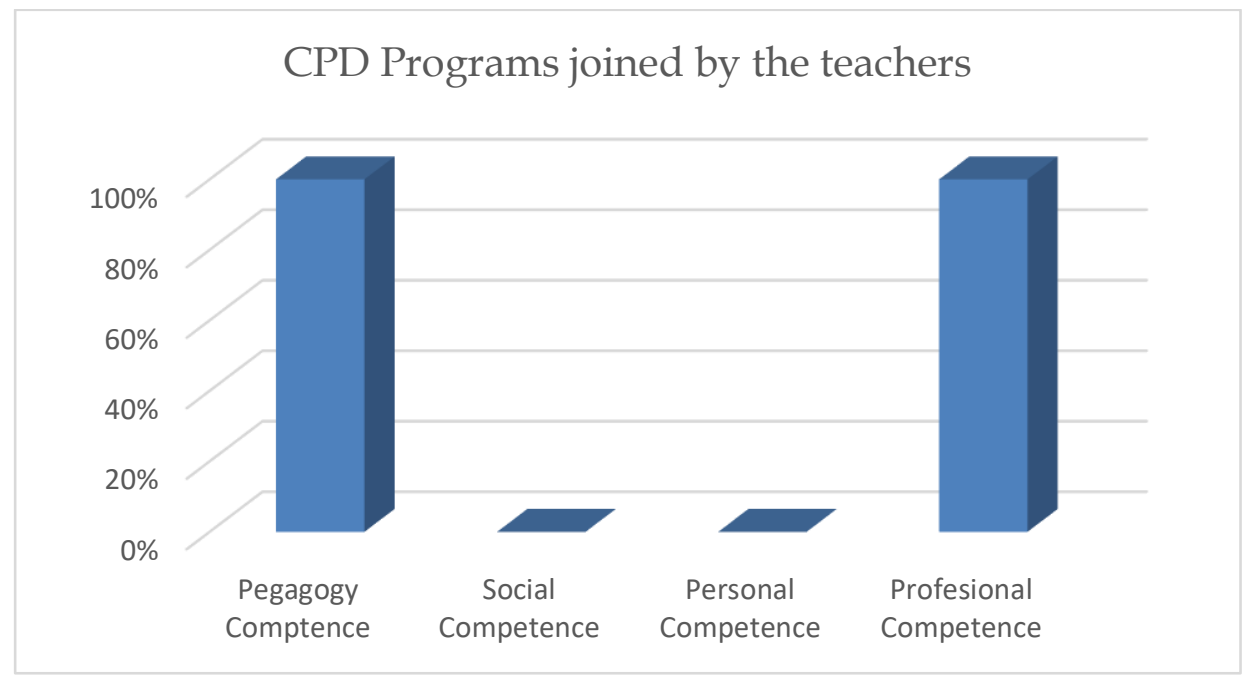

Chart 2. CPD Programs joined by the teachers

\section{British council's components in CPD}

After the interview, the participants were asked to fill out a questionnaire about which development activities they had received during their career as teachers. This questionnaire was developed based on the 12-CPD components developed by the British Council. The results obtained from this questionnaire are sufficient to confirm the findings of the interviews where the components related to the development of pedagogical competences and professional competences still rank at the top. Meanwhile, the components included in the social and personal competencies lack attention from interested parties.

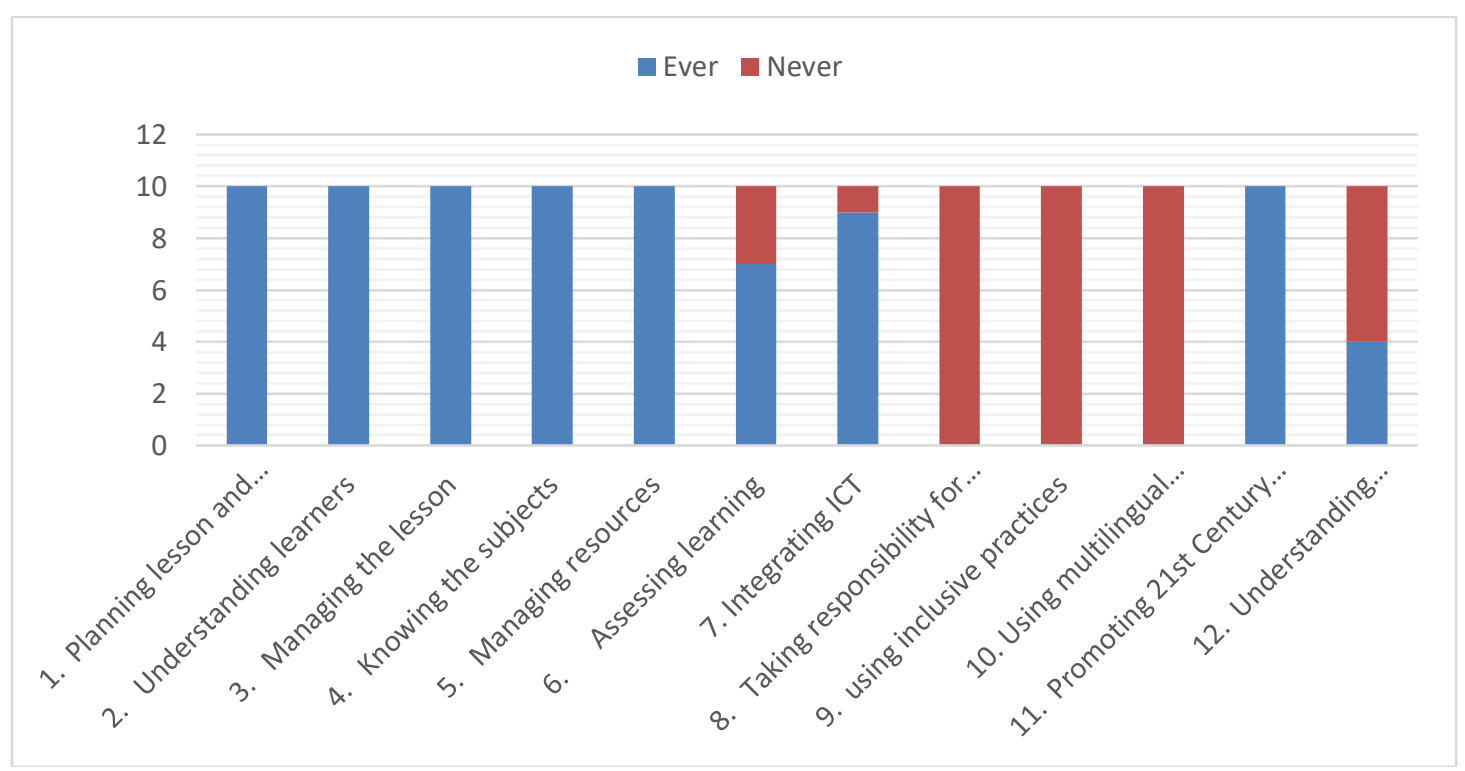

Chart 3. British Council's components in CPD 


\section{Factors in continuous professional development}

In the interview, the participants explained that there are several important factors that determine whether teachers in these schools will have the opportunity to participate in teacher development programs or not. These factors are school leadership, teachers age, employment status, and education qualification.

The first factor is the school leadership. This factor becomes an important determinant of where the school principals act as the policy authority to make the program. As a leader, the principal can make programs to develop the professionalism of the teachers who are structurally under the principal. In the interview, three types of school principals were found, whose types had an effect on opportunities for professional development for the teachers. The first type is the innovative principal. This type of principal is the school leader who has high concern and visionary for the development of the quality of human resources in the school he/she leads and has many ideas for development programs so that the people under him/her are motivated to follow the program that has been planned. The second type is the accommodating principal. The leader who accommodate the needs of teaching staff opens opportunities for teachers in their schools to make suggestions for self-development. This gives teachers a good chance of CPD. While the third type is the passive one. Working as usual and running a program like the previous year makes innovation less visible and there is a lack of opportunities for teachers and staff to gain professional development. Among the three types of leaders, innovative leaders can be found in private schools located in urban areas. Then accommodating leadership can be found in urban and rural public schools. Meanwhile, the passive type is found in rural public schools.

The second factor is age. This factor turned out to influence the attitudes of the participants in this study. Among the ten participants, some were over 50 years old. The response was given by the participants where young people tend to participate more in self-development activities than older ages. Especially, in terms of developing pedagogical competencies that apply learning technology in the classroom. This is because many new technologies are no longer familiar to older teachers so they have difficulty operating some of these new technologies.

The third factor is employment status. Some of the senior teacher who have status as civil servants from rural areas tend to be absent from selfdevelopment programs designed and planned by stakeholders such as the Education authority, associations, or schools. Indeed, these findings cannot be generalized because in urban schools, this status does not really have an influence on teacher motivation to participate in self-development programs. 
The last factor is the factor of education qualification. All participants stated that they had serious views regarding educational qualifications. The first thing that concerns them is the suitability of the educational background with the subjects being taught by the teacher. In some schools in rural areas, there are still teachers who have academic qualifications that do not match the subjects being taught. This, of course, can be one of the findings from the perspective of teacher professional development. Then the second concern that was found was the level of education (whether S1 or S2) also had an impact on understanding and actions in their professional development.

\section{DISCUSSION}

Continuous Professional Development (CPD) is a necessity to get good quality education (Lessing \& Witt, 2007; Manutede et al., 2015). The government plays a role in this because it is the jurisdiction of the government to regulate (Vodenko, 2019). As part of the government's efforts to maintain this quality, the Law on Teachers and Lecturers Number 13 Year 2005 was passed. In the law, teachers are required to have all specified competencies. The participants in this study were aware of this competency so that they reflect as a teacher, they had an obligation to develop their quality in a professional manner. Thus, quality assurance will be achieved. This is in line with previous findings, although different in terms of sampling where this study was taken randomly and in the previous study, the sample were taken purposively on exemplary teachers (Anugerahwati \& Saukah, 2010).

This research shows how teachers in East Kalimantan have an awareness that they have an obligation to develop themselves so that they can become professional teachers. With the support of various parties, CPD is implemented by various stakeholders such as the Education Authority, associations, and schools using their respective budget ceilings. Even some teachers who are dedicated to professional development participate in various training programs using their personal individual funds. According to a study (Appova \& Arbaugh, 2018), some factors that drive the teachers to invest their time and effort as well as money to CPD were, first, their personal dissatisfactions towards their current performance and the image of optimum teaching instruction. Second, too much focus on quantity such as pursuing numbers of hours of training as the paperwork requirement may discourage teacher from getting quality CPD. There has to be balance between quality and quantity. Third, the stakeholders' funds investment is essential for supporting them so that the teacher will not feel skeptical about the commitment to quality CPD. So, each party has the correlation in implementing CPD (Supriatna, 2005). Every party must have planning and implementation of teacher professional development (Bolitho \& Padwad, 2013). 
However, it needs to be the concern of all parties that most professional development programs created by stakeholders are too focused on only some parts of the aspects required by law (Appova \& Arbaugh, 2018). These findings were also confirmed by data obtained from the British Council's CPD development instrument. So far, many training programs have focused on pedagogical competences and professional competences, such as class and curriculum planning, class management, learning evaluation, information technology integration, responsibility for professional development, and understanding of education policies and their implementation. Previous studies also focused on professional competence only (Mustafa, 2013). A comprehensive training and development program will provide maximum results for the output of the program (Bolitho \& Padwad, 2013).

Apart from the type of program being made, another thing that concerns this study is that there are other factors that have an impact on the CPD of teachers in schools, both individually and collectively. These factors include school leadership, teacher age, employment status, and education. The innovation from the leadership will ensure the sustainability of the quality of teachers. This research provides additional factors apart from the policy, moral and financial aspects (Tanang \& Abu, 2014).

The age and employment status must also be a concern of policy makers and the findings should be used as material for policy discussion so that this situation can be shifted. Theoretically, teachers who are more senior and have civil servant status should have a higher CPD awareness and become more skilled due to decades of experience in teaching (Saputra et al., 2020). So that seniority can be a positive thing where these teachers can be a reference from their colleagues at the institution to become role models.

Education qualifications also have an influence on the professional development of teachers in both private and public schools. The findings in this study are interesting because of previous studies where private schools have lower awareness than public schools (Qoyyimah, 2018). In fact, the private schools in Balikpapan and Samarinda are well resourced in terms of CPD. Teachers in private schools have the opportunity to regularly develop their professionalism. The school has full support for this. If we look deeper, one of the reasons is that these private schools are well-managed schools with healthy cash flow so that quality is an important concern of the school foundation and management. Thus, the argument that the status of honorary employees will reduce professionalism and private schools do not provide opportunities for teachers to develop competencies, can be refuted by this finding. 


\section{CONCLUSION}

As the main indication of teacher professionalism, the four professional teacher competencies were generally well recognized by the participants who are from various schools from three districts / cities in East Kalimantan. This is a good starting point for teachers in each school. The thing that still has to be a concern is how the stakeholders can maintain the sustainability of the programs that have been made. On the other hand, the disconnection between each stakeholder makes CPD, which should be programmed in a structured and measured manner, less effective. Moreover, based on the findings, the training and development programs carried out were more focused on pedagogical competence and professional competence, which made two other competencies such as social and personal competence neglected.

The factors associated with achieving CPD for individual teachers are leadership, age, employment status, and educational level or qualifications of the teacher. These factors are related, where the leader will open opportunities for CPD, and others can also support. Employment status where civil servants usually feel safer, prompting some senior teachers to limit themselves to getting CPD. This can be used as evaluation for stakeholders. Last, the factor that is not less important is the education qualification factor in which education to a higher level is part of the CPD itself.

Based on the above conclusions, the researcher provides several suggestions: For stakeholders, CPD is a crucial part of maintaining the quality of education. CPD that is well-programmed and measured will be the guarantee of the quality of the education itself. So, it is imperative for each party to work together to provide a sustainable teacher professional development program with good cooperation between all stakeholders. It should also be noted that the CPD given to teachers is in accordance with the mandate of the law so that expectations of professional and competent teachers will be achieved.

Teachers and schools need to be aware that CPD is the obligation of each individual and institution. So that the factors of leadership, age, employment status, and education can be used as part of the consideration for making a CPD program. Thus, a good CPD will be open to all individuals.

This research still has limited funds and time so that the sampling is still limited. So that the characteristics of the results of this study are attached to cases with situations that occurred. Follow-up research with larger participants with a wider variety of school status and geo-social conditions will provide a more comprehensive picture. This research also opens the door for other researchers to take a deeper look at how CPD activities and programs will impact teaching practices in the classroom; how far the CPD process is part of the internalization of each stakeholder, how the CPD affect the academic culture of the entire school academic community. 
Continuous professional development: An overview from English language teachers...

\section{ACKNOWLEDGMENTS}

We would like to express gratitude to the Directorate of Research and Community Service of the Ministry of Higher Education of Republic of Indonesia year 2019 for the funding of this research. We also thank the editor as well as the anonymous reviewers for valuable feedback on this paper.

\section{REFERENCES}

Anugerahwati, M., \& Saukah, A. (2010). Professional Competence of English Teachers in Indonesia: A Profile of Exemplary Teachers. Indonesian Journal of English Language Teaching, 6(6), 47-59.

Appova, A., \& Arbaugh, F. (2018). Teachers' motivation to learn: Implications for supporting professional growth. Professional development in education, 44(1), 5-21.

Bolitho, R., \& Padwad, A. (2013). Continuing Professional Development, Lesson from India. British Council.

Carr, W., \& Kemmis, S. (1986). Becoming Critical: Education, Knowledge, and Action Research. In Canadian Journal of Education / Revue canadienne de l'éducation (Vol. 13, Issue 1). RoutledgeFarmer, Taylor \& Francis Inc. https://doi.org/10.2307/1495177

Undang-Undang Republik Indonesia Nomor 14 Tahun 2005 Tentang Guru dan Dosen, Pub. L. No. 14 (2005).

Lessing, A., \& Witt, M. De. (2007). The value of continuous professional development : teachers' perceptions. South African Journal of Education, 27(1), 53-67.

Manutede, Y. Z., Susiloningsih, E., \& Ridlo, S. (2015). Pengembangan Instrumen Kompetensi Pedagogis Guru Smp Dalam Kurikulum 2013 Menurut Persepsi Guru Di Kota Salatiga. Journal of Educational Research and Evaluation, 4(2), 116-123. https://doi.org/10.15294/jrer.v4i2.9917

Mustafa, M. N. (2013). Professional Competency Differences among High School Teachers in Indonesia. International Education Studies, 6(9), 83-92. https://doi.org/10.5539/ies.v6n9p83

Qoyyimah, U. (2018). Policy implementation within the frame of schoolbased curriculum: a comparison of public school and Islamic private school teachers in East Java, Indonesia. Compare, 48(4), 571-589. https:// doi.org/10.1080/03057925.2017.1334536

Saputra, D. B., Suherdi, D., \& Rodliyah, R. S. (2020). REFLECTIVE PRACTICE AS TOOLS TO EXPLORE IN-SERVICE TEACHERS' BELIEFS AND CLASSROOM PRACTICES: INDONESIAN EFL TEACHERS' VOICES. Journal of Applied Linguistics and Literature, 5(2). https://doi.org/https://doi.org/10.33369/joall.v5i2.11260

Supriatna, A. (2005). Indonesia's issues and challenges on teacher professional development. CICE Series, 2(2), 29-42. 
Tanang, H., \& Abu, B. (2014). Teacher Professionalism and Professional Development Practices in South Sulawesi , Indonesia. Journal of Curriculum and Teaching, 3(2), 25-42. https://doi.org/10.5430/jct.v3n2p25

Vodenko, K. V. (2019). Problems and perspectives of state regulation of system of education in the context of provision of Russia's national security. International Journal of educational management, 33 (3).

\section{THE AUTHOR}

Abdul Halim is a lecturer at Universitas Muhammadiyah Kalimantan Timur. His research interests are in language education, multicultural education, curriculum research, and instructions.

Yih-Sheue Lin is a professor at National Dong Hwa University, Department of Education and Human Potentials Development. Her research interests include multicultural teaching strategies and culturally responsive teaching, Vygotsky and sociocultural theory, reading instruction, college teaching, playful parenting, and academic language

Mustofa is a lecturer at Universitas Nahdlatul Ulama Surabaya. His research interests are in the field of social education, civic education, gender roles, and history education.

Khusnul Khatimah is a lecturer at Universitas Muhammadiyah Kalimantan Timur. Her research interests are in language education, teaching English as a second language, curriculum research, and instructions. 